\title{
Historical GIS: application of map-based biography to the Laeva sovkhoz / state farm, Estonia
}

\author{
Martti Veldi ${ }^{1}{ }^{1}$ and Simon Bell ${ }^{1}$ \\ ${ }^{1}$ Estonian University of Life Sciences, Chair of Landscape Architecture, Tartu, Estonia
}

\begin{abstract}
In the MODSCAPES project the concept of historical GIS is one of the practical research tools to detect, map, and analyse largescale landscape changes caused by modernist rural development schemes. Historical GIS enables us to synthesise human interactions with their surrounding landscape on temporal and spatial axes. In this paper, historical GIS is applied to create a map-based biography of one of the case study examples, Laeva, which was a collective state farm or sovkhoz in South Estonia between 1975 and 1993. Through combining historical maps and archival data we followed the process of collectivisation in Laeva. The Laeva sovkoz was a result of nearly 30 years of trial and error in collective farming, which in the area started with the establishment of seven small kolkhozes in 1948 and 1949. In the 1950s the small kolkhozes were amalgamated into larger and more effective agricultural units. After several mergers and reorganisation of production, in 1975 the sovkhoz of Laeva was established. In the second half of the 1970s the sovkhoz became an experimental cattle and pig breeding research institute of the Estonian Agricultural Academy. We also compared the land use dynamics of the area before, during, and after the collectivisation. The results showed that during the collectivisation the pressure to cultivate land was intensified, and through extensive melioration wetlands were drained, and forested.
\end{abstract}

\section{Introduction}

In 1969 landscape architect lan McHarg, author of Design with Nature [1] introduced the method of "map overlay", which enabled landscape planners to deconstruct a region into separate, easily manipulated layers of landscape features. This method later became the main concept of what have since become geographical information systems (GIS). Since the 1990s, besides other fields, GIS has also been extensively applied in historical geography and long-term landscape research. This has resulted with the emergence of a specialised sub-discipline, referred to as "historical GIS". The underlying concept of historical GIS is to combine the disciplines of history and geography - it is not about space on its own, but about interrelations between people set in space and time, which create places in the landscape. Historical GIS enables us

\footnotetext{
${ }^{1}$ Corresponding author: martti.veldi@emu.ee
} 
to synthesise human interactions with their surrounding landscape on temporal and spatial axes.

In the MODSCAPES project the concept of historical GIS is one of the practical research tools to detect, map, and analyse large-scale landscape changes caused by modernist rural development schemes. In this paper, it is applied to create a map-based biography of one of the case study examples, Laeva, in Estonia, which was a state farm or sovietskoye khoziaistvo or sovkhoz.

\section{Background}

Landscape development has been very strongly influenced by the relations between landowners and dwellers. It has been argued that each socio-economic formation creates its own landscape with its own symbols and value systems. Hence, changes in society also bring along alterations in function, meaning and perceptions of land and landscape [2, 3].

Immediately after the end of the Second World War the Soviet Union started to make preparations for the collectivisation of agriculture in the newly conquered territories such as Estonia, with the aim of turning private property into collective ownership. The painful process of collectivisation started in 1947, when the first five collective farms were established in Estonia. More intensive collectivisation started in 1949, which was to a large extent triggered by the mass deportation initiated in March 1949. By the end of 1949 most of the agricultural land had been collectivised and only the poorest farms, whose owners were in less fear of deportation, remained untouched. They were incorporated in collective farms between 1949 and 1951, after the rise of taxes on agricultural land. Sovkhoz $z^{2}$ or state farms were similar to kolkhoz except that the farmers were employees rather than members.

In the 1950s the smallest and most financially struggling collective farms were amalgamated into larger and more effective agricultural units. During the 1960s and 1970 s a focus was put on the specialisation of the collective farms in order to explore possibilities that were more suitable for the local land conditions and human resources. By the end of the 1980s, just before the collapse of the Soviet Union and the collective farming system, a large number of Estonian kolkhozes and sovkhozes were doing the best they could economically, given the circumstances. Some of them were even economically quite successful.

To follow this process in more detail, we have chosen the experimental sovkhoz of Laeva in South Estonia as a case study. Applying methods of historical GIS, we created a map-based biography of the Laeva sovkhoz and its land use during the $20^{\text {th }}$ century. To understand the effect of the landscape change during different political regimes, we studied the land use change before, during, and after the collectivisation.

\footnotetext{
${ }^{2}$ Sovkhoz - abbreviation from Russian советское хозяйство, Soviet ownership. Type of collective farm owned by the state and run by workers who were paid.

${ }^{3} \mathrm{Kolkhoz}$ - abbreviation from Russian коллективное хозяйство, collective ownership. Type of collective farm, where the land was owned by the state, but the moveable assets and machinery and the products were owned by the members.
} 


\section{Method and sources}

We started with the manor borders from the 1900s, cadastral and physical maps from the end of the 1930s, Soviet agricultural and topographical maps from the 1960s-1980s and ending with the current situation from the 2010s.

The maps included in the analyses are:

1. General maps of Kursi ${ }^{4}$ and $\mathrm{Äksi}^{5}$ parishes with manor borders dating from 1900.

2. Topographic map (1935-1939) of the Republic of Estonia, at the scale of 1: 50000 is the best map characterising the land use conditions between the two world wars ${ }^{6}$.

3. Cadastral map (1930-1944) of the Republic of Estonia. The map conveys the effects of the land reform initiated in 1919 and gives a good overview of how the Early Modern manor/peasant landscape was turned into a landscape of private farms ${ }^{6}$.

4. Agricultural map of Tartu rajoon ${ }^{7}$ dating from $1960^{8}$.

5. Agricultural map of Laeva collective farm from $1979^{9}$.

6. Topographic map of Soviet Estonia at the scale of 1:50 000, the parts in the study region which were produced in 1989. The map indicates large-scale land use changes carried out during the Soviet times, especially melioration (drainage) of both forest and agricultural land ${ }^{6}$.

7. Estonian Basic map (2010s) digital version at the scale of 1: 10000 is the most accurate map on the contemporary land use. Comparison with the topographic map of 1935-1939 enables the detection of large scale changes that took place during the Soviet collective farming ${ }^{10}$.

The land use data on the raster maps provided by the Estonian Land Board WMSservice were vectorised into polygons and lines and given necessary attribute data using ArcGIS software. The Äksi and Kursi parish maps, and also the agricultural maps of Tartu rajoon and Laeva sovkhoz had first to be georeferenced with Earth's coordinates in ArcGIS, and then vectorised. The study area was defined by the borders of Laeva in 1979, when the sovkhoz was its largest.

Historical maps were complemented with archival data from the yearly reports of the collective farms stored at the National Archives of Estonia.

\section{Results}

\section{From manor landscape to private plots}

At the end of the $19^{\text {th }}$ century the study area included lands from three Baltic-German manors. Most of the land belonging to the later Laeva sovkhoz was in 1900 owned by Laeva (Laiwa) and Kärevere (Kerafer) manors, both established in the $17^{\text {th }}$ century. A smaller part of the land was a separate land unit of Sootaga (Sotaga) manor (Fig. 1.).

\footnotetext{
${ }^{4}$ EAA.3724.5.2569. Kspl. Talkhof. Krs. Dorpat. National Archives of Estonia.

${ }^{5}$ EAA.3724.5.2702. Ksp. Ecks, Krs. Dorpat. National Archives of Estonia.

${ }^{6}$ ESTONIAN LAND BOARD PUBLIC WMS.

https://geoportaal.maaamet.ee/est/Teenused/Avalik-WMS-teenus-p65.html

${ }^{7}$ Rajoon - administrative unit in the Soviet Union, comparable to county.

${ }^{8}$ ERA.T-6.5.58. Eesti NSV Tartu rajooni põllumajanduslik kaart. National Archives of Estonia.

${ }^{9}$ LAEVA SOVHOOSI MAAKSUTUSPLAAN. Archive of the National Heritage Board.

${ }^{10}$ EESTI PÕHIKAARDI VEKTORKAART. Estonian Land Board.
} 


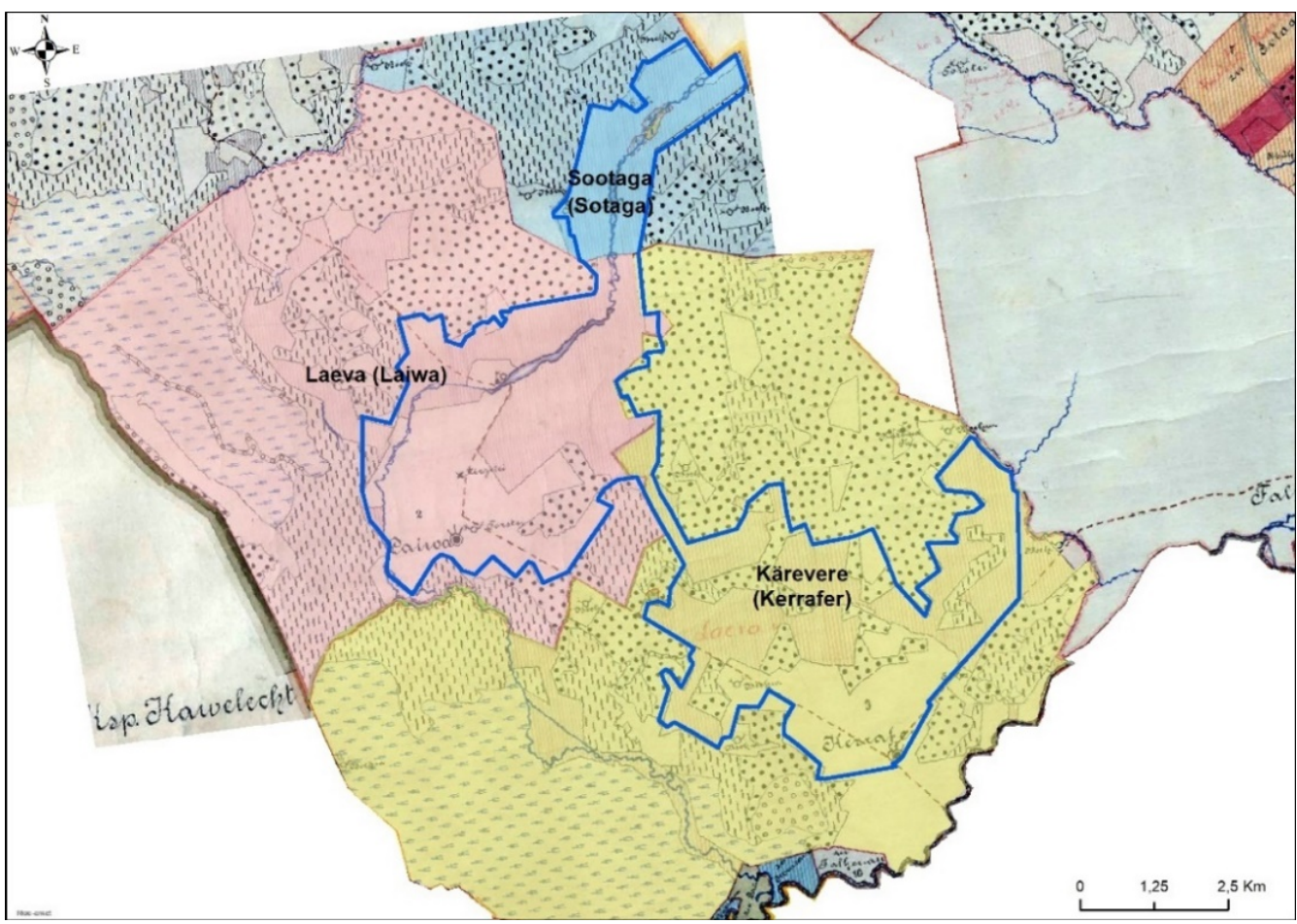

Figure 1. In 1900s the land belonging to the later Laeva sovkhoz was owned in 1900 by Laeva (Laiwa), Kärevere (Kerafer), and Sootaga (Sotaga) manors (Source: Base map provided by the Estonian Land Board).

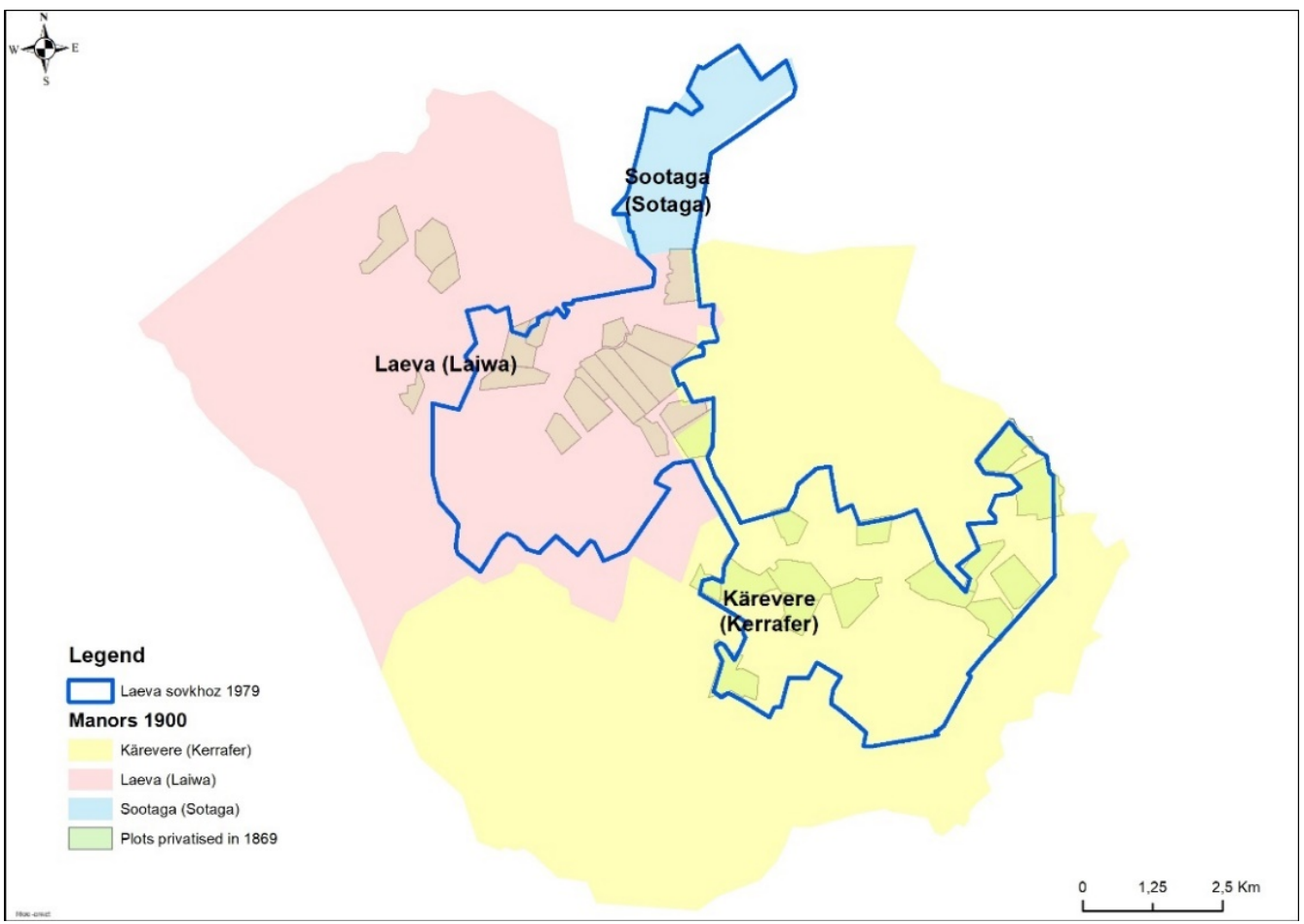

Figure 2. Private plots bought by peasants from Laeva and Kärevere manors in 1869 (Source: Base map provided by the Estonian Land Board). 
After servitude of peasants was abolished in 1816 in Estonia (today North Estonia) and Livonia (today South Estonia), and the peasant law of 1856, peasants were given the right to rent or buy land from the landlord. We know that by 1869 in both Laeva and Kärevere manors, 21 peasants had taken the opportunity to buy their land from the landlord (Fig. 2.).

With the parcellation of communal lands, the existing feudal land structure started slowly to change into a landscape of private farmsteads. However, the most profound change in land ownership relations did not come until 1918 with the independent republic of Estonia. The land reform of 1919 initiated the nationalisation of Baltic-German manors, and the core areas of feudal estates were given as rewards to the soldiers who had participated in the War of Independence from Bolshevik Russia. In many places, the main manor buildings were turned into schools or hospitals [6].

Data extracted from the cadastral map completed in 1944 demonstrated that the area of Laeva sovkhoz was divided between 263 plots, of which 116 plots had belonged to Laeva manor, 114 to Kärevere manor, and 26 to Sootaga manor (Fig. 3.).

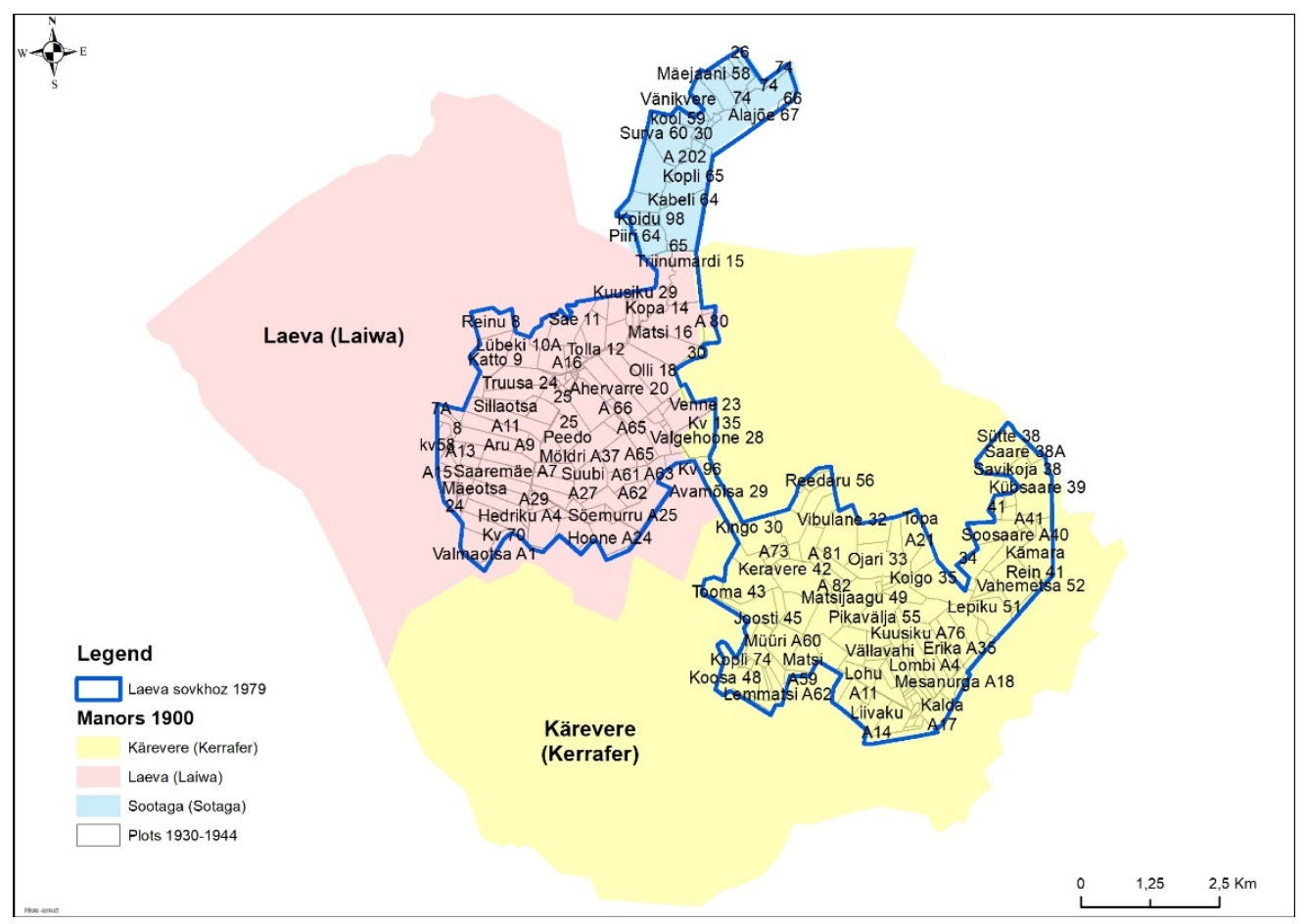

Figure 3. Plots allocated from Laeva and Kärevere manor after the land reform initiated in 1919 (Source: Base map provided by the Estonian Land Board).

\section{Formation and amalgamation of collective farms}

In the years 1948 and 1949, seven small kolkhozes were established in the later area of Laeva collective state farm (Fig. 4.). The first kolkhoz to be founded on $18^{\text {th }}$ of September 1948 was named after the Estonian novelist Anton Hansen Tammsaare. The centre of the kolkhoz was established at the Ojari farm, its former owner Arnold Reinhold was named as a kulak and, as an enemy of the state, he was deported to Siberia later in March 
$1949^{11}$. Before its amalgamation with other collective farms in the area, the Tammsaare kolkhoz had 21 members, of which only 5 were men between the ages of $16-60^{12}$. Also, the core area of the first kolkhoz consisted of only 5 neighbouring farms. Slightly bigger were the collective farms of "Areng" (Development) and "Punane Koit" (Red Dawn) with 50 and 60 people respectively belonging to the kolkhozes by 1949 . Other collective farms founded in the area in 1948 and 1949 were "Tee Tõusule (Road to Rise), "Edasi" (Forward), and "Kodu" (Home). Also, the total area of these first kolkhozes was relatively small, ranging between 375 and 741 hectares.

In 1951, all the small kolkhozes were united into two large collective farms named "A. H. Tammsaare" and "Areng" (Fig. 5.).


Figure 4. By 1949, in the area 7 small collective farms had been established (Source: Base map provided by the Estonian Land Board).

\footnotetext{
${ }^{11}$ EAA.T-168.1.245. Täitevkomitee otsused P-901 - P-1361. National Archives of Estonia.

${ }^{12}$ EAA.T-560.1.8. Kolhooside 1950. a aastaaruanded, A. H. Tammsaare nimeline, Kodu, Tee Tõusule / Kärevere külanõukogu. National Archives of Estonia.
} 


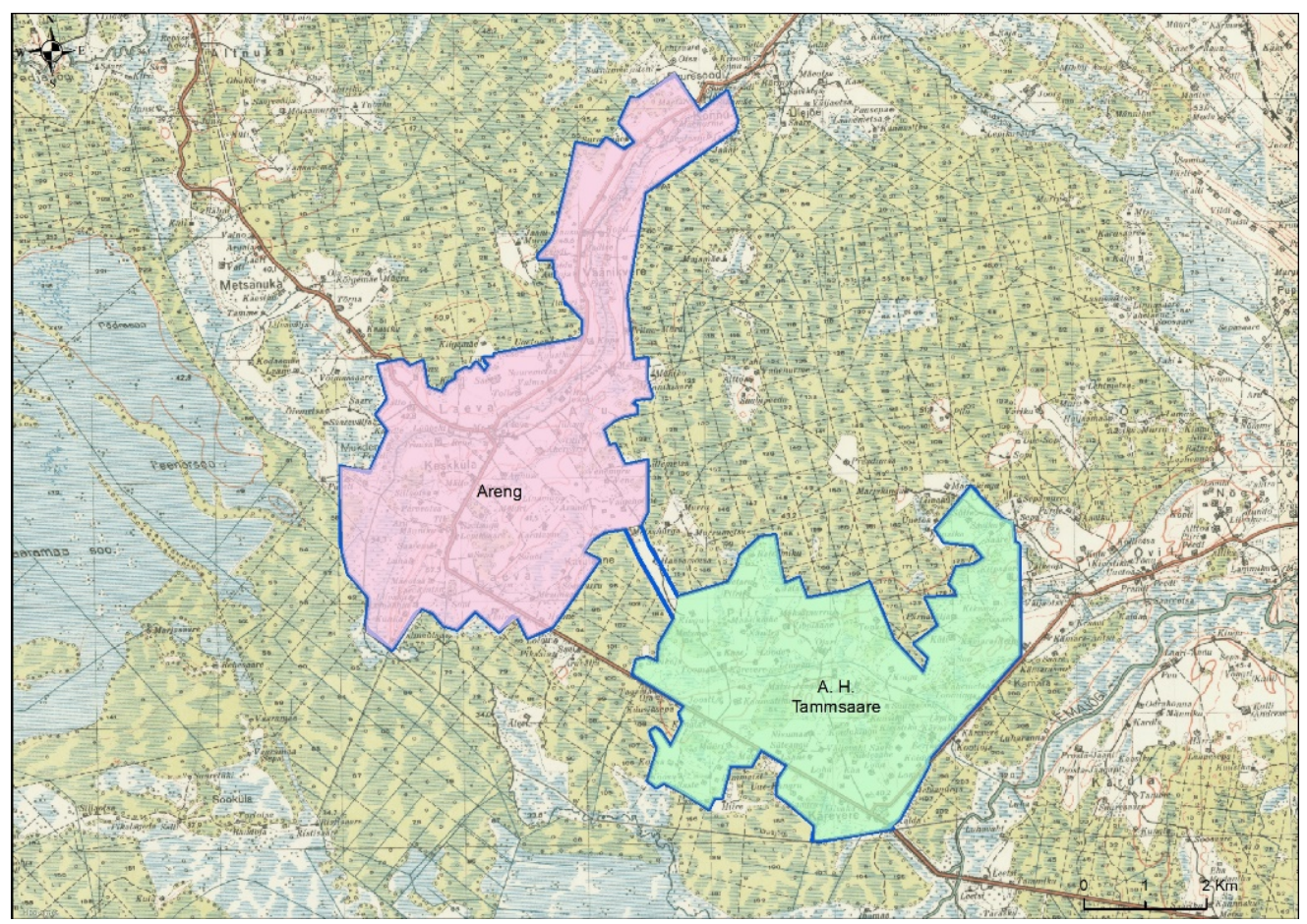

Figure 5. In 1951, the seven small collective farms were amalgamated into two larger kolkhozes "Areng" and A. H. Tammsaare (Source: Base map provided by the Estonian Land Board).

\section{Formation of the collective state farm in Laeva}

By the end of 1955 the economic situation in the collective farm "Areng" had become so critical, that the Ministry of Meat and Dairy Industry of the Estonian Soviet Socialist Republic decided to restructure the kolkhoz into a state owned collective farm sovkhoz. From now onwards, the farm would get orders directly from the state Animal Fund office (Vabariiklik Loomavaru kontor). The overall plan to get the collective farm back on its feet, was to specialise on feeding and fattening cattle before slaughter underfed cattle from other collective farms were to be brought to Laeva, where they were properly fed, and then taken to the slaughter house [7].

In 1958, the A. H. Tammsaare kolkhoz was united with the cattle feeding farm "Areng" and ended its 10-year existence ${ }^{13}$, being the longest functioning first collective farm in the area. However, the sovkhoz was still in financial difficulties for another 20 years, and only started to emerge out of poverty after 1975, when it was reorganised into an experimental state farm under the Estonian Scientific Research Institute of Animal Breeding and Veterinary (Eesti Loomakasvatuse ja Veterinaaria Teadusliku Uurimise Instituut), which was a research institute of the Estonian Agricultural Academy (and which eventually became the Estonian University of Life Sciences). From 1975 to 1992, the Laeva experimental state farm was directed by a zootechnician, Aavo Mölder, who introduced scientific research and methods in cattle and pig breeding. In 1992, Mölder became the minister of agriculture of the restored Republic of Estonia [7].

${ }^{13}$ EAA.T-2006.1.32. A. H. Tammsaare nimelise kolhoosi sovhoosile ülevõtmise akt ja materjalid. National Archives of Estonia. 


\section{The collapse of Laeva sovkhoz}

Just some years before the collapse of the Soviet Union in 1991, the state owned experimental collective farm of Laeva was prosperous and doing well. Although, with only 4700 hectares of land was one of the smallest state farms in Soviet Estonia, in the 1980 s it developed into an efficient dairy and pork farm boasting high production numbers and awards of socialist workmanship [8]. With the collapse of the Soviet Union the collective economy also collapsed, and despite various efforts, survival in the new economic and political conditions turned out to be impossible. In 1993 the farm announced its bankruptcy. The assets of the sovkhoz were sold at an auction for 2 million Estonian crowns [9].

With the new land reform initiated in 1990 land was given back to their rightful owners, and today the former area of the Laeva sovkhoz is divided between private, municipal and state-owned plots.

\section{Land use dynamics}

Based on the historical maps we compared the land use dynamics of the area of the Laeva collective state farm in three periods: 1) 1930s 2) 1980 s and 3) 2010s.

Throughout the $20^{\text {th }}$ century the area was actively used agriculturally (Fig. 6.). From the topographic map of the 1930s we can see that the landscape was a mosaic and divided between agricultural land and semi-natural grasslands in lower and wetter areas (Fig.7.). In the 1930s, agricultural land formed almost $60 \%$ of the study area, the percentage of grassland and wet grassland constituted together about $25 \%$. Only around $9 \%$ of the land was covered in forest, of which $2 / 3$ were situated on wet lowlands.

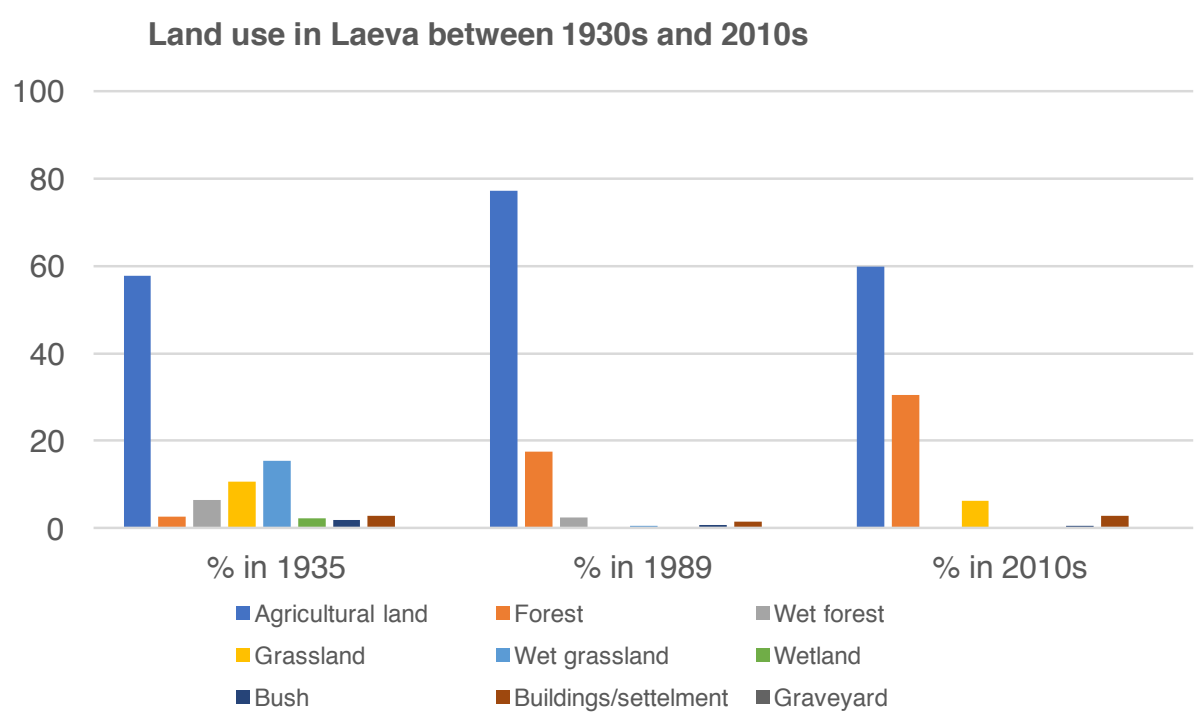

Figure 6. Land use dynamics in the study area between the 1930s and 2010s. 



Figure 7. The landscape of the 1930s can be characterised as mosaic, divided between agricultural land and semi-natural grasslands in lower and wetter areas (Source: Base map provided by the Estonian Land Board).

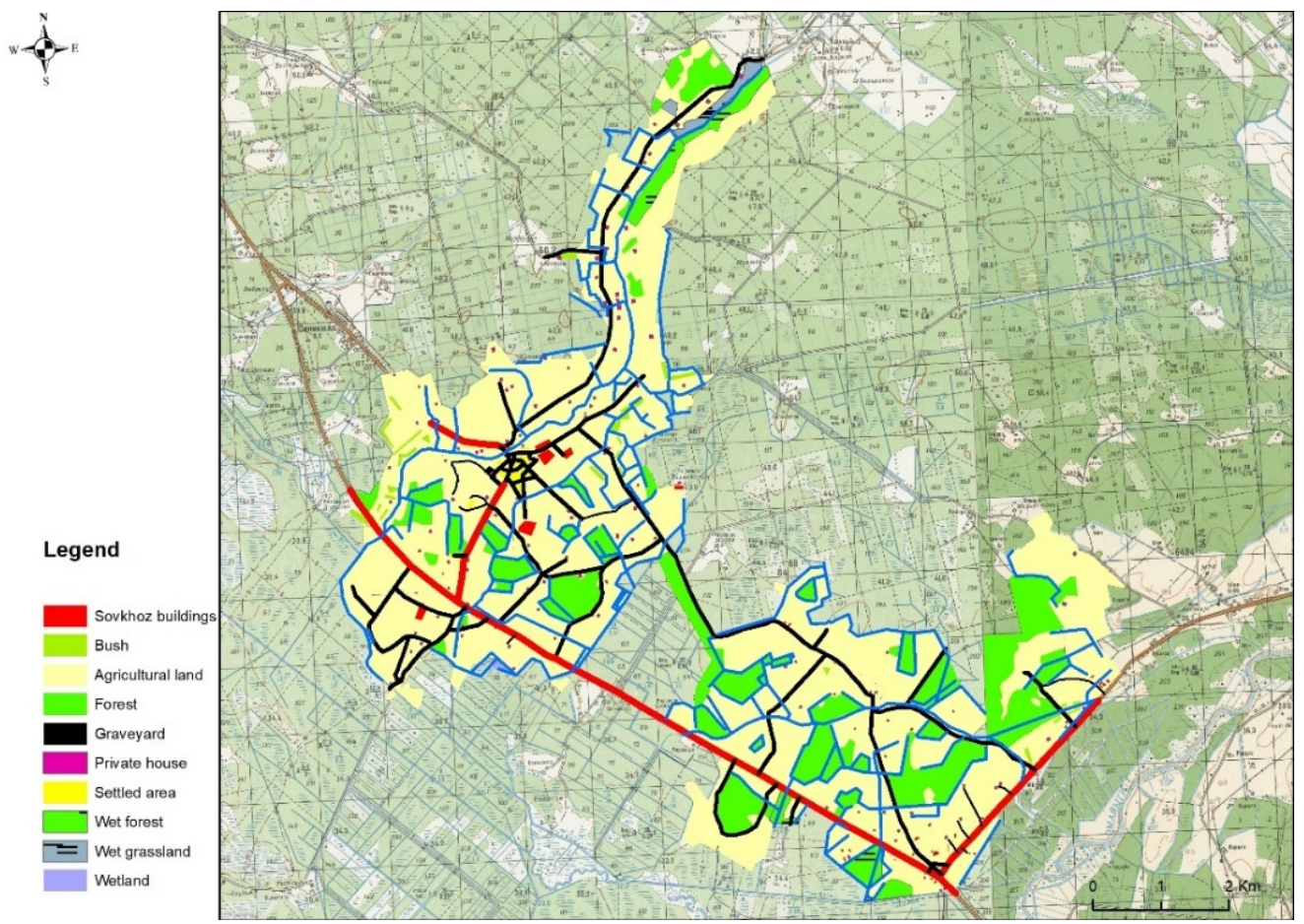

Figure 8. Landscape of the collective farm. Wet areas have been drained by melioration, and most of agricultural land has been taken into use (Source: Base map provided by the Estonian Land Board). 


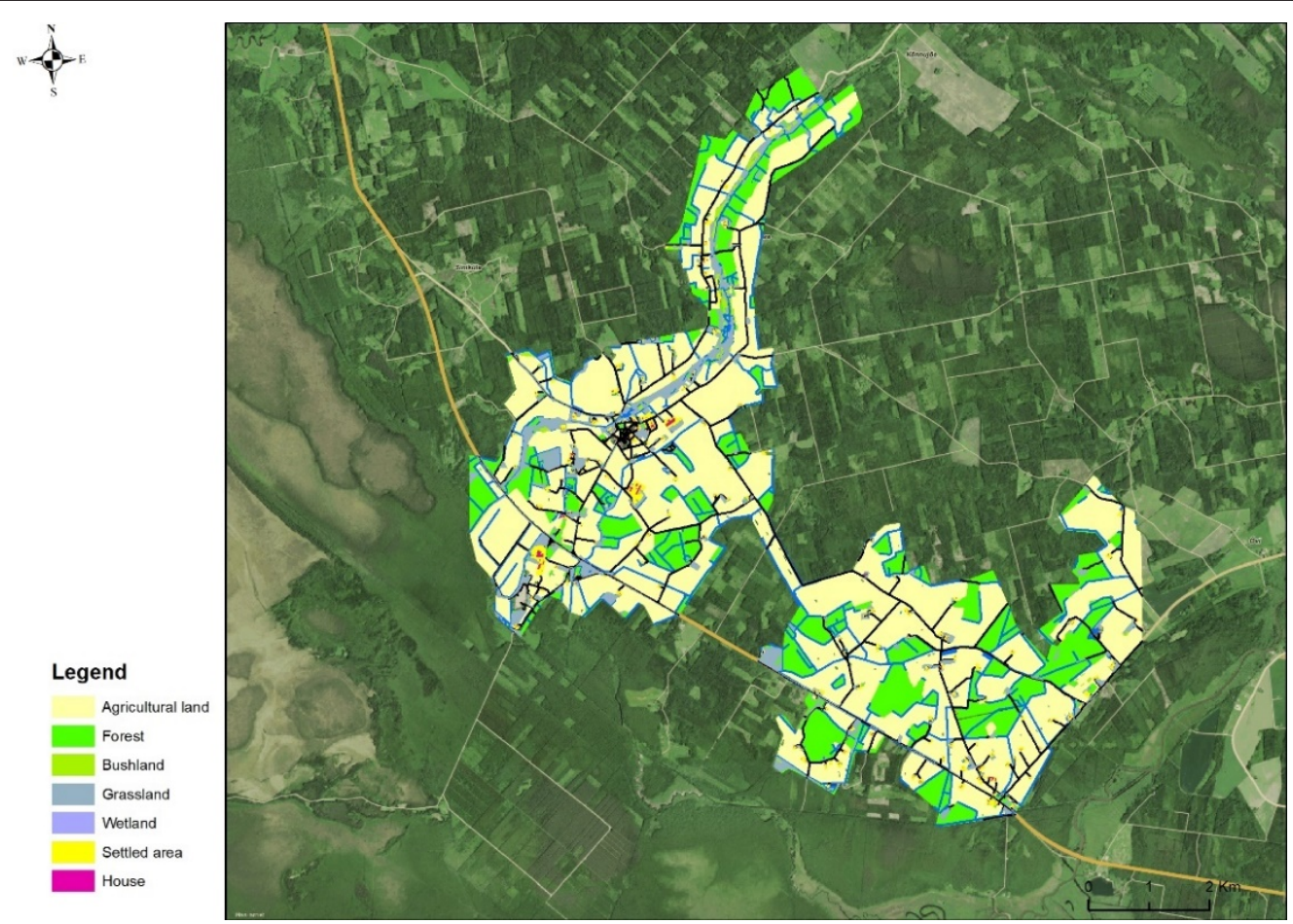

Figure 9. Land use at the former Laeva sovkhoz in the 2010s (Source: Base map provided by the Estonian Land Board).

During the Soviet times pressure to cultivate land was intensified, and most of the land which was suitable for agriculture was put into use ending up as almost $80 \%$ of the study area (Fig. 8.). At the same time, wetlands were drained by melioration, and on the grasslands and low lying areas, the percentage of forest grew from $9 \%$ to more than $17 \%$. Also, the 1930s' landscape of private plots was dismantled, and the village of Laeva became a densely settled centre of the area.

In the 2010s (Fig. 9.), we can see that the percentage of agricultural land had fallen back almost on the same level as it was in the 1930s. At the same time, the amount of forest had risen up to more than $30 \%$. The wetlands had been drained but compared to the 1980 s the percentage of open grassland had gone up more than $6 \%$.

\section{Conclusions}

In the case of Laeva we can detect the pattern where at first relatively small and very poor kolkhozes were established in 1948-1949, which were later united into larger ones to even out short comings. After several mergers, small kolkhozes were united into one large sovkhoz.

Laeva collective state farm achieved its glory and largest extent at its final stage or development between 1975 and 1995, when it was run as an experimental farm of the Estonian Agricultural Academy, mainly focusing on breeding efficient dairy cows and pigs. The quality of the land in Laeva was quite low because of clay soils, and was not suitable for grain growing, so cattle breeding was more efficient and profitable.

The application of historical GIS can be very revealing but has some challenges, such as matching maps from different scales, with different levels of detail and cartographic systems, coordinates etc. This approach presented here shows both the 
process of land ownership and administration through looking at boundaries and also the physical changes that took place - the major role of melioration (land drainage) and the advance of forest in some places, the construction of drainage ditches and new roads, all of which changed the appearance and, together with the built structures, provide the physical remains which, if a person knows what to look for, enable a reading of these latest layers in the landscape to be undertaken.

This study also showed that collectivisation was something of a messy process, subject to inefficiencies and changes in policy and practice. It was, ironically, only at the very end of the Soviet era that the system became reasonably efficient and economically effective and then afterwards there was little or no viability.

\section{Acknowledgements}

MODSCAPES is a collaborative research project funded under the HERA - Humanities in the European Research Area 3rd Joint Research Programme dedicated to "Uses of the Past" (20162019). This project has received funding from the European Union's Horizon 2020 research and innovation programme under grant agreement $n^{\circ} 649307$.

\section{Short resumes}

Martti Veldi MSc is an archaeologist and a Junior Researcher at the Estonian University of Life Sciences in Tartu, Estonia. He is also an inspector in the Estonian Heritage board responsible for identifying and protecting cultural heritage monuments.

Simon Bell PhD is Chair professor at the Estonian University of Life Sciences and Associate Director of the OPENspace Research Centre at the University of Edinburgh. He has been president of ECLAS, the European Council of Landscape Architecture Schools between 2012 and 2018.

\section{References}

1. MCHARG, I. 1969. Design with Nature, New York, John Wiley and Sons.

2. COSGROVE, D. 1984. Social formation and symbolic landscape, University of Wisconsin Press.

3. PALANG, H.; SOOVÄLI, H.; PRINTSMANN, A. et al. 2004. "Estonian cultural landscapes: persistence and change", in J.-M. Punning (ed.), Estonia. Geographical studies 9, Tallinn, Akadeemia Kirjastus [Estonian Academy Publishers]: 155-170.

Retrieved from: https://www.etis.ee/File/DownloadPublic/33615a6c-4a71-4ba1be3a-c2972d8a83f6?name=Fail_Estonian\%20cultural\%20landscapes\%20\%20persistence\%20and\%20change.PDF [available on 14 March 2019].

4. PALANG, H.; PRINTSMANN, A.; KONSA, M. et al. 2005. "Ideology and tradition in landscape change: a case of the Helme parish, Estonia", in T. Peil, M. Jones (eds.), Landscape, Law and Justice: Proceedings of a Conference Organised by the Centre for Advanced Study, (Norwegian Academy of Science and Letters, Oslo, 15-19 June 2003), (Instituttet for sammenlignende kulturforskning, Serie B - Skrifter: 118), Oslo, Novus: 288-297. 
Retrieved from: https://www.etis.ee/File/DownloadPublic/b397927a-10c8-40e89bf6-

e3806e26c538?name=Fail_Ideology\%20and\%20tradition\%20in\%20landscape $\% 20$ change $\% 20$ -

$\% 20$ a 20 case $\% 20$ of $\% 20$ the $\% 20$ Helme $\% 20$ parish $\% 2$ C $\% 20$ Estonia.pdf\&type= application\%2Fpdf [available on 14 March 2019].

5. TAMM, V. 2012. Aegade kaja. Laeva valla ajalugu [The Echo of Times. History of the Laeva Municipality], Laeva vald.

6. PINO, N. 1984. "Tänades sooviti jõudu" [Thanks for your strength], Edasi, 24 January.

7. POSTIMEES, 1993. Postimees, 18 May. 